\title{
Peripheral Nervous System Manifestations Associated with COVID-19
}

\author{
Sasan Andalib ${ }^{1}$ - José Biller ${ }^{2}$ - Mario Di Napoli ${ }^{3} \cdot$ Narges Moghimi $^{4} \cdot$ Louise D McCullough $^{5} \cdot$ Clio A. Rubinos $^{6}$. \\ Christa $\mathrm{O}^{\prime}$ Hana Nobleza ${ }^{7}$. M. Reza Azarpazhooh ${ }^{8} \cdot$ Luciana Catanese $^{9} \cdot$ Isabel Elicer $^{10} \cdot$ Mostafa Jafari $^{11}$. \\ Fabrizio Liberati ${ }^{12}$. Claudia Camejo ${ }^{13}$. Michel Torbey ${ }^{4}$. Afshin A. Divani ${ }^{4}$
}

Accepted: 21 January 2021 / Published online: 14 February 2021

(C) The Author(s), under exclusive licence to Springer Science+Business Media, LLC part of Springer Nature 2021

\begin{abstract}
Purpose of Review The present review discusses the peripheral nervous system (PNS) manifestations associated with coronavirus disease 2019 (COVID-19).

Recent Findings Nerve pain and skeletal muscle injury, Guillain-Barré syndrome, cranial polyneuritis, neuromuscular junction disorders, neuro-ophthalmological disorders, neurosensory hearing loss, and dysautonomia have been reported as PNS manifestations in patients with COVID-19.

Summary Severe acute respiratory syndrome coronavirus 2 (SARS-CoV-2) causes COVID-19. COVID-19 has shown syndromic complexity. Not only does SARS-CoV-2 affect the central nervous system but also it involves the PNS. The PNS involvement may be due to dysregulation of the immune system attributable to COVID-19. Here we review the broad spectrum of PNS involvement of COVID-19.
\end{abstract}

Keywords COVID-19 $\cdot$ SARS-CoV-2 $\cdot$ Peripheral nervous system manifestations

\section{Introduction}

Coronaviridae are common pathogens of the respiratory system. Two important outbreaks of coronavirus infections,

This article is part of the Topical Collection on Neurology of Systemic Disease

Afshin A. Divani

adivani@gmail.com

Sasan Andalib

andalib@health.sdu.dk

José Biller

jbiller@lumc.edu

Mario Di Napoli

mariodinapoli@katamail.com

Narges Moghimi

narges.moghimi@gmail.com

Louise D McCullough

louise.d.mccullough@uth.tmc.edu

Clio A. Rubinos

crubinos@unc.edu

Christa O'Hana Nobleza

christaohana14md@yahoo.com namely severe acute respiratory syndrome coronavirus (SARS-CoV) and Middle East respiratory syndrome coronavirus (MERS-CoV), have emerged in the past decades. Since December 2019, there has been an increasing number of

\author{
M. Reza Azarpazhooh \\ azarpazhoohr@gmail.com \\ Luciana Catanese \\ luciana.catanese@phri.ca \\ Isabel Elicer \\ isabel.elicer@gmail.com \\ Mostafa Jafari \\ mostafa.jafari@bcm.edu \\ Fabrizio Liberati \\ f.liberati@asl.rieti.it \\ Claudia Camejo \\ ccamejo@adinet.com.uy \\ Michel Torbey \\ mtorbey@salud.unm.edu
}

Extended author information available on the last page of the article 
patients affected by coronavirus disease 2019 (COVID-19), caused by severe acute respiratory syndrome coronavirus 2 (SARS-CoV-2). The virus has a 79.5\% [1] and 50\% [2] gene sequence homology to SARS-CoV and MERS-CoV, respectively. During the current pandemic, the medical community has faced enormous challenges. The public health burden of COVID-19 has become one of the highest among infectious respiratory illnesses. There has been a widening pattern of central nervous system (CNS) involvement associated with COVID-19 [3•]. Furthermore, a growing body of literature links COVID-19 to peripheral nervous system (PNS) manifestations. In the present review, we discuss the PNS manifestations associated with COVID-19.

\section{Neuropathophysiology of COVID-19}

SARS-CoV-2 is a beta-coronavirus with a 29,903 base singlestranded RNA genome that belongs to the Orthocoronavirinae subfamily, which is part of the Coronaviridae family. Structurally, SARS-CoV-2 has a well-defined composition comprising of 14 binding residues. Spike (S) glycoprotein receptor on the surface of SARS-CoV-2 binds to angiotensin-converting enzyme 2 (ACE2) receptors expressed on various host tissues [4-8], enabling endocytosis of the virion. Data suggests that the neurovirulence of SARS-CoV2 could be related to the degree of expression of the ACE receptor in the nervous system. However, this receptor is expressed in the smooth muscle cells in the endothelium. Therefore, it is necessary to investigate further its role in the etiopathogenesis of neurological complications [9]. In the internalization process of SARS-CoV-2, transmembrane protease serine 2 (TMPRSS2), furin, and cathepsins B and L (Cat B and $\mathrm{L}$ ) trim the $\mathrm{S}$ glycoprotein and facilitate its binding to ACE2 and SARS-CoV-2 cell entry [10•].

SARS-CoV-2 has shown several degrees of neurotropism. It has been proposed that the virus can enter the nervous system from PNS terminals of the olfactory nerve and the nasal olfactory epithelium, a probable site of enhanced binding of SARS-CoV-2. Bilinska et al. [11] showed that ACE2 and TMPRSS2 are expressed in the olfactory epithelium's sustentacular cells, suggesting that these cells may be involved in SARS-CoV-2 virus entry and smell impairment. Notably, the expression of the entry proteins is increased in older animals, thus possibly explaining why older individuals are more susceptible to SARS-CoV-2 infection [11]. Additionally, another possible transsynaptic route from the nasal respiratory epithelium to the brain via the trigeminal nerve branch has recently been hypothesized, although this needs verification [12]. Furthermore, an alternative proposed pathway was also proposed indicating a retrograde spread via transsynaptic transfer using an endocytosis or exocytosis mechanism and a fast axonal transport mechanism of vesicle transport moving the virus along microtubules back to neuronal cell bodies [13]. Autopsy of patients with COVID-19 showed that viral RNA is present in the CNS $[14,15]$.

In the nervous system, SARS-CoV-2 induces downregulation of ACE2, underactivating the renin-angiotensin system (RAS)'s alternative pathway (ACE2-Ang-(1-7)-Mas). Such underactivation, in turn, leads to overactivation of the classical RAS pathway (ACE-Ang II-AT1R). These can result in oxidative stress, neuroinflammation, vasodilation, and thrombotic events. Animal models showed that the brain cortex was unevenly involved with infected cells visible in columnar patches and sensory regions, a high density of infected cells in most brain regions except for the cerebellum and that SARS-CoV-2 can induce a disruption in vascular topology at the cortex [16]. It has been suggested that the virus affects the respiratory centers in the brainstem [17].

\section{Cytokine Storm in COVID-19}

No unifying definition of cytokine storm exists. There is much disagreement about what the definition should be and whether specific conditions such as COVID-19 should be included in the spectrum of cytokine storm disorders [18]. Nevertheless, cytokine storm due to COVID-19 triggers coagulopathy and thrombosis [19]. SARS-CoV-2 can also bind to toll-like receptors, enabling interleukin (IL)-1 synthesis and release [20, 21]. Activation of this receptor leads to a biochemical cascade starting with the production of pro-IL-1 cleaved by caspase-1, which is followed by inflammasome activation. IL-6 is also elevated in COVID-19 [22]. IL-6 is an important proinflammatory mediator that can induce an immune response in the nervous system, leading to brain tissue injury [23] and stroke [24]. The level of IL-6 is correlated with the severity of COVID-19 symptoms [25]. Type I interferon (IFN) dysregulated in COVID-19 can affect innate and acquired immunity [20]. Most COVID-19 patients also exhibit increased circulating levels of IL-2, IL-8, IL-17, granulocyte colony-stimulating factor, granulocyte-macrophage colony-stimulating factor, interferon gamma-induced protein 10 , and monocyte chemoattractant protein 1 [26]. Nevertheless, IFN release can result in inflammation and immune system suppression [27]. These key features represent a maladaptive immune response characterized by hyperactivity of innate immunity followed by immunosuppression.

\section{PNS Manifestations of COVID-19}

COVID-19 may affect the PNS even before the resolution of pneumonia, meeting diagnostic criteria for acute polyradiculoneuropathy [28]. Stuart-Neto et al. [29] reviewed records of 89 patients with COVID-19. The authors found that 
$3(6.7 \%)$ out of 45 COVID-19 patients with severe respiratory conditions developed peripheral neuropathy. The PNS involvement may be caused by SARS-CoV-2 dysregulating systemic immune response. Systemic hyper-inflammation with macrophage activation syndrome, also known as secondary hemophagocytic lymphohistiocytosis, has been proposed in COVID-19 patients [30]. These immune-mediated manifestations occur typically after the acute phase of the infection subsides [31].

\section{Guillain-Barré Syndrome Spectrums}

Guillain-Barré syndrome (GBS) has been reported following COVID-19. The clinical spectrum of GBS encompasses a classic sensorimotor form, Miller Fisher syndrome, bilateral facial palsy with paresthesias, pure motor, pure sensory, paraparesis, pharyngeal-cervical-brachial variants, polyneuritis cranialis (GBS-Miller Fisher syndrome overlap), and Bickerstaff brainstem encephalitis. Regarding the electrophysiological features, several main subtypes are recognized, including acute inflammatory demyelinating polyneuropathy (AIDP) and acute motor-sensory axonal neuropathy (AMSAN) [32]. Classic GBS is characterized by acute-onset ascending sensorimotor polyneuropathy [33]. Both GBS and acute motor axonal neuropathy (AMAN) have been reported after SARS-CoV and MERS-CoV infections [34, 35]. Furthermore, peripheral motor neuropathy has also been reported before the onset of the typical flu-like symptoms of COVID-19 [36-38]. A post-infectious dysregulation of the immune system arising from COVID-19 is presumably the cause of GBS [39]. A molecular mimicry mechanism in which infecting viruses likely share epitopes similar to some peripheral nerve components is believed to occur and stimulate autoreactive T or B lymphocytes [39]. GBS can further complicate COVID-19 outcomes. Published case reports of GBS cases occurring post-COVID-19 have been published from China, the USA, Europe, and the Middle East (see Table 1) $[28,36,37,40-70,71 \bullet \cdot]$. In a review of 37 published GBS cases associated with COVID-19, Caress et al. [38] reported a mean age of 59 years, and $65 \%$ were males. One systematic review [72••] of COVID-19 patients with GBS found that the interval between COVID-19 symptoms onset and the first symptoms of GBS ranged from 8 to 24 days. Most of the patients had a typical GBS clinical presentation with a predominantly demyelinating subtype on electrophysiological studies. Mechanical ventilation was necessary for eight (44\%) patients. Two (11\%) patients died. Another report showed that the majority of COVID-19-related GBS patients had AMAN and ASMAN phenotypes [73]. Even so, a few of these patients had enhancement of caudal nerve roots on gadolinium-enhanced MRI of the spine. Miller Fisher syndrome, a rare variant of GBS, has also been reported in
COVID-19 patients [74]. Most of these patients received hydroxychloroquine, azithromycin, lopinavir, and ritonavir, as well as intravenous immunoglobulin (IVIG). Yet, more than half of these patients exhibited poor outcomes in the form of prolonged intensive care unit (ICU) stay, residual paresis, and dysphagia [73]. A systematic review of 42 COVID-19 patients with GBS showed a $40.5 \%$ ICU admission rate, with one-third of the patients having respiratory failure [75]. Since case reports mostly shape the body of the literature on COVID-19 and GBS, it cannot be excluded that they present coincidentally. A recent epidemiological study in the UK does not confirm a causal link of COVID-19 to GBS [76]. The annual incidence of GBS in UK hospitals was 1.66 to 1.88 per 100,000 people for the years 2016 to 2019 . Significantly fewer GBS cases were reported for March, April, and May 2020 (93, 70, and 56, respectively) compared with 2016-2019 mean case numbers for the same months (132, 116 , and 113 , respectively) [76]. It is suggested that lockdown measures may have reduced the transmission of other GBStriggering pathogens and could explain the decline in observed cases in 2020, although unascertained since the attendance bias in a pandemic cannot be excluded.

\section{Nerve Pain, Myalgias, and Skeletal Muscle Injury}

In Wuhan, Mao et al. [77] studied 214 patients with COVID19 of which 88 and 216 patients showed severe and nonsevere symptoms. Nerve pain was found in $4(4.5 \%)$ and 1 $(0.8 \%)$ of the patients with severe and non-severe COVID-19, respectively. Skeletal muscle injury was seen in 17 (19.3\%) and $6(4.8 \%)$ of the patients with severe and non-severe COVID-19, respectively. It is important to consider that reports of creatine kinase (CK) elevation, as the only marker of muscle injury, are non-specific and may be related to prolonged bed rest and medications in severe COVID-19 cases more than a direct muscle injury from COVID-19. In the ALBACOVID registry, myopathy and myalgia were seen in $3.1 \%$ and $17.2 \%$ of the COVID-19 patients, respectively [71 ••]. Myalgias were reported in $15.79 \%$ to $100 \%$ of COVID19 patients in other published studies [26, 78-90].

\section{Myopathy and Myositis}

Myositis can be a manifestation of COVID-19, although most literature only involves case reports. A patient with diffuse myalgias and proximal lower limb muscle weakness, causing him to fall, showed a bilateral hip flexion deficit with $3 / 5$ muscle strength [91]. There were bilateral external obturator muscle and quadricipital edema on his proximal lower limb MRI, and bilateral myositis was confirmed. The patient was 
Table 1 Peripheral nervous system manifestations in patients with COVID-19

\begin{tabular}{|c|c|c|c|c|}
\hline Manifestation & Rate and features & Study type & Location & Author, year, ref \\
\hline \multirow{16}{*}{$\begin{array}{l}\text { Nerve pain, myalgia, } \\
\text { and skeletal muscle } \\
\text { injury }\end{array}$} & $\begin{array}{l}\text { Nerve pain in } 5(2.3 \%) \text { of } 124 \text { patients; skeletal muscle } \\
\text { injury in } 23(10.7 \%) \text { patients }\end{array}$ & Retrospective & China & Mao et al., 2020 [77] \\
\hline & $\begin{array}{l}\text { Myopathy and myalgia in } 3.1 \text { and } 17.2 \% \\
\text { of } 841 \text { patients, respectively }\end{array}$ & Retrospective & Spain & Romero-Sanchez et al., 2020 [71••] \\
\hline & Myalgias in $52 \%$ of 25 adult patients & Retrospective & China & Han et al., 2020 [78] \\
\hline & Myalgias in $44 \%$ of 41 patients & Prospective & China & Huang et al., 2020 [26] \\
\hline & Myalgias in $52 \%$ of 62 patients & Retrospective & China & Xu et al., 2020 [88] \\
\hline & Myalgias in $70 \%$ of 30 patients & Retrospective & China & Liu et al., 2020 [80] \\
\hline & Myalgias in $23.75 \%$ of 80 patients & Retrospective & China & Wang et al. 2020 [79] \\
\hline & Myalgias in $100 \%$ of 14 patients & Retrospective & China & Wei et al., 2020 [89] \\
\hline & Myalgias in $62.5 \%$ of 1420 patients & Retrospective & $\begin{array}{l}18 \text { European } \\
\text { hospitals }\end{array}$ & Lechien wt al., 2020 [81] \\
\hline & Myalgias in $45.5 \%$ of 110 patients & Retrospective & China & Lai et al., 2020 [82] \\
\hline & Myalgias in $57 \%$ of 1487 patients & Retrospective & France & Lapostolle et al. 2020 [83] \\
\hline & Myalgias in $15.79 \%$ of 38 patients & Retrospective & China & Chen et al., 2020 [84] \\
\hline & Myalgias in $19 \%$ of 80 children & Retrospective & Turkey & Korkmaz et al., 2020[90] \\
\hline & Myalgias in $67 \%$ of 14 patients & Prospective & Australia & O’Reilly et al., 2020 [85] \\
\hline & Myalgias in $38.46 \%$ of 26 patients & Case series & India & Gaur et al., 2020 [86] \\
\hline & Myalgias in $43.75 \%$ of 32 patients & Retrospective & India & Aggarwal et al., 2020 [87] \\
\hline \multirow[t]{28}{*}{ GBS } & $\begin{array}{l}4 / 5 \text { muscle strength in both arms and hands and } 3 / 5 \\
\text { muscle strength in both legs and feet }\end{array}$ & Case report & China & Zhao et al., 2020 [36] \\
\hline & $\begin{array}{l}2 / 5 \text { muscle strength in the lower extremity, } 3 / 5 \text { upper } \\
\text { extremities strength }\end{array}$ & Case report & USA & Virani et al., 2020 [40] \\
\hline & 5 patients & Case series & Italy & Toscano et al., 2020 [41] \\
\hline & Paraplegia, $4 / 5$ muscle strength in the upper limbs & Case report & Italy & Ottaviani et al., 2020 [44] \\
\hline & Right peripheral facial nerve palsy & Case report & Spain & Juliao Caamano et al., 2020 [45] \\
\hline & $\begin{array}{l}\text { Acute-onset bilateral facial weakness, dysarthria with } \\
\text { labial sounds, and paresthesia in the feet }\end{array}$ & Case report & Canada & Chan et al., 2020 [42] \\
\hline & Bilateral lower motor neuron pattern of facial weakness & Case report & USA & Hutchin et al., 2020 [43] \\
\hline & $\begin{array}{l}\text { 4/5 symmetric muscle strength of distal upper and lower } \\
\text { limbs }\end{array}$ & Case report & Italy & Padroni et al., 2020 [46] \\
\hline & Quadriplegia & Case report & Iran & Sedaghat et al., 2020 [47] \\
\hline & Bilateral lower limb flaccid paresis & Case report & Switzerland & Coen et al., $2020[48]$ \\
\hline & Flaccid severe tetraparesis & Case report & France & Camdessanche et al., 2020 [49] \\
\hline & Motor predominant peripheral neuropathy & Case report & UK & Abdelnour et al., 2020 [37] \\
\hline & $\begin{array}{l}\text { One patient with Miller Fisher syndrome } \\
\text { and one patient with polyneuritis cranialis }\end{array}$ & Case report & Spain & Gutiérrez-Ortiz et al., 2020 [50] \\
\hline & Miller Fisher syndrome & Case report & USA & Lantos et al., $2020[51]$ \\
\hline & Miller Fisher syndrome & Case report & USA & Rana et al. [52], 2020 \\
\hline & Miller Fisher syndrome & Case report & Spain & Reyes-Bueno et al., 2020 [53] \\
\hline & Miller Fisher syndrome & Case report & Germany & Senel et al., 2020 [54] \\
\hline & Miller Fisher syndrome & Case report & Spain & Fernández-Domínguez., 2020 [55] \\
\hline & Miller Fisher syndrome & Case report & Italy & Manganotti et al., 2020 [56] \\
\hline & $\begin{array}{l}\text { Hypesthesia of the left mandibular region, paresis of } \\
\text { both upper limbs, and problem with ambulation }\end{array}$ & Case report & Spain & Diez-Porras et al., [57] \\
\hline & $\begin{array}{l}\text { Generalized areflexia, bilateral peripheral facial } \\
\text { paralysis, and decreased sensation in distal limbs }\end{array}$ & Case report & USA & Paybast et al., 2020 [58] \\
\hline & $\begin{array}{l}\text { Hypoglossal nerve palsy, limb hyporeflexia, and } \\
\text { demyelinating pattern in the limbs }\end{array}$ & Case report & Italy & Assini et al., 2020 [59] \\
\hline & Severe flaccid tetraparesis & Case report & Italy & Alberti et al., 2020 [28] \\
\hline & GBS with dysautonomia & Case report & USA & Su et al., $2020[60]$ \\
\hline & Paraparesis, areflexia, numbness, and dysphagia & Case report & Germany & Scheidl et al., 2020 [61] \\
\hline & $\begin{array}{l}\text { Mild dysarthria due to jaw weakness and bilateral, } \\
\text { predominant lower limb weakness, slight weakness } \\
\text { in hand muscles, and decreased sensation to } \\
\text { pin-prick distally to the upper thighs }\end{array}$ & Case report & Turkey & Oguz-Akarsu et al., 2020 [62] \\
\hline & $\begin{array}{l}\text { Quadriplegia, hypotonia, areflexia, and bilateral } \\
\text { positive Lasègue sign }\end{array}$ & Case report & Morocco & Otmani et al., 2020 [63] \\
\hline & $\begin{array}{l}\text { The first case showed weakness in the lower limb, right } \\
\text { peripheral facial palsy, ataxia, reduced light touch } \\
\text { from midthigh to feet and the tip of the fingers, } \\
\text { reduced vibration sense in the lower limbs, }\end{array}$ & Case report & France & Bigaut et al., 2020 [64] \\
\hline
\end{tabular}


Table 1 (continued)

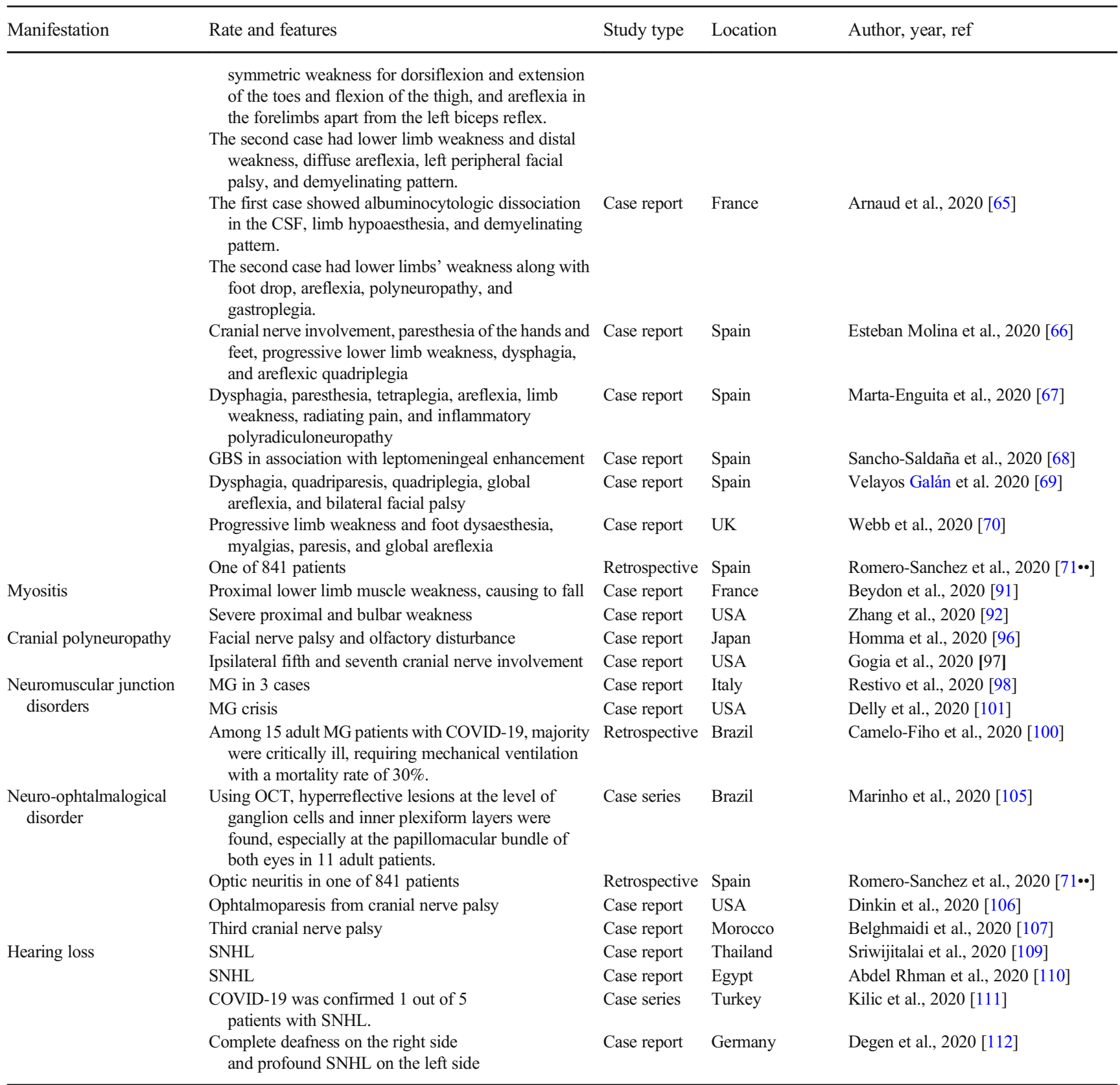

FLAIR, fluid-attenuated inversion recovery; $G B S$, Guillain-Barré Syndrome; $I C A$, internal carotid artery; $M G$, myasthenia gravis; $M R C$, Medical Research Council; $O C T$, optical coherence tomography; $N M S$, neuroleptic malignant syndrome; $S N H L$, sensorineural hearing loss

diagnosed as having COVID-19 by a chest CT scan and PCR testing. A case report of a 58-year-old woman with COVID19 showed a hypernasal type of dysarthria, facial weakness, bilateral eyelid ptosis, profound symmetric proximal limb weakness, and reduced muscle stretch reflexes [92]. Her MRI did not demonstrate any signs of CNS and PNS involvement; nevertheless, diffuse muscle edema and enhancement were demonstrated with a region of myonecrosis. Her motor and sensory nerve conduction study (NCS) of the relevant nerves was unremarkable. Electromyography (EMG) of the right vastus lateralis, deltoid, and iliopsoas muscles showed sparse fibrillation potentials. Her CK level increased on admission. Regenerating fibers, perivascular inflammatory infiltration with endomysial extension, and upregulation of human 
leukocyte antigen class $\mathrm{ABC}$ expression on non-necrotic fibers was shown using muscle biopsy. The patient was diagnosed as having a COVID-19-associated myositis.

Mehan et al. [93] performed a retrospective cohort study at a single large academic institution. Between March 3, 2020, and May 6, 2020, 641 patients presented with COVID-19. A total of 9 patients underwent spine MRI scan to evaluate pathology with indications including back pain, lower extremity weakness, and lower extremity paresthesia. Four of the $9 \mathrm{MR}$ imaging examinations were performed with contrast. None of these patients had been previously treated for myositis. Six of the 9 patients required admission to the hospital to treat COVID-19, where 4 of these patients were intubated. Seven of $9(78 \%)$ patients who underwent spine MRI demonstrated myositis on MRI with the erector spinae and multifidus muscles' involvement. In all 7 patients with MRI findings of myositis, it occurred exclusively in the lumbar spine and involved multiple vertebral body levels. In all cases, the myositis was bilateral. In the seven patients with lumbar spine MRI who had imaging findings suggestive of myositis, the edema in the paraspinal musculature was out of proportion to the degree of superficial subcutaneous edema.

Our unpublished work indicated that COVID-19 patients could also develop an inflammatory myopathy characterized by proximal muscle weakness, elevated serum muscle enzyme levels where muscle biopsy showed significant myofiber necrosis and minimal, if any, lymphocytic infiltrates characterizing an immune-mediated necrotizing myopathy (IMNM), sometimes referred to as necrotizing autoimmune myopathy (NAM), representing a distinct type of myositis included in the most recent classification schemes of the inflammatory myopathies and different from previous ones described. The histopathological features of IMNM comprise myonecrosis, myophagocytosis, regeneration, and a relative paucity of lymphocytic infiltration. The myonecrosis is scattered, and different stages of necrosis, myophagocytosis, and muscle fiber regeneration are observed, indicating temporal evolution. Macrophages are the predominant mononuclear cell type, whereas T and B cells were very scant. Non-specific features, including focal tissue sclerosis, muscle fiber size variation, and nuclear centralization, were present (Fig. 1). The inflammatory infiltrate was primarily composed of macrophages (CD68/PGM1+) along with scant lymphocytes B/CD20+ and $\mathrm{T} / \mathrm{CD} 3+$ with a T-helper immunophenotype (CD4+), as well as CD123+ plasmacytoid dendritic cells. To date, two different autoantibodies have been described in association with IMNM, those recognizing the signal recognition particle (SRP) and those targeting hydroxy-3-methylglutaryl-CoA reductase (HMGCR). Both autoantibodies were not identified. The presence of elevated CK levels and proximal weakness is insufficient to diagnose the myopathy subtype in COVID-19 patients, making it necessary to obtain a muscle biopsy to demonstrate the characteristic features of a necrotizing myopathy. COVID-19 may represent a possible trigger of IMNM. Exposure to the virus could generate an immune response due to molecular mimicry [94]. Notably, there are no clinical trials to guide therapeutic decisions in COVID-19related IMNM. Therefore, the following recommendations are derived from personal experience: corticosteroids (IV, 0.5-1 g/day, 3-5 days) and IVIG for refractory disease, which may be considered as monotherapy for patients who have contraindications to the use of steroids (IVIG $2 \mathrm{~g} / \mathrm{kg}$ in 5 days).

\section{Multiple Cranial Neuropathies}

Recent evidence indicates that COVID-19 may also lead to multiple cranial neuropathies, as well as the more recognized high incidence of anosmia with infection, with rates of up to $73 \%$ of those infected [95]. A 35-year-old COVID-19 patient had the right facial paralysis and olfactory disturbances [96] and an almost complete loss of sense of taste on the right side of her tongue, with only the preservation of a sense of sweetness. Her sense of smell was also completely absent as she could not smell shampoo, coffee, or soy sauce. One report of a patient with ipsilateral fifth and seventh cranial nerve involvement that started within 5 days of respiratory symptoms and resolved in 3 weeks suggests that multiple cranial neuropathies may be a manifestation of COVID-19 [97].

\section{Neuromuscular Junction Disorders}

New-onset myasthenia gravis (MG) after COVID-19 infection can also occur and may also be due to molecular mimicry mechanisms as with other neurological manifestations. This was suggested by Restivo et al. [98] after describing three cases of new-onset acetylcholine receptor antibody-positive (antiAChR+) MG after COVID-19. Indeed, there is evidence that COVID-19 can trigger autoimmunity through the augmentation of $\mathrm{T}$ cell signaling [99]. Acute respiratory distress (ARDS) seen in COVID-19 coupled with respiratory muscle failure in $\mathrm{MG}$ crises may result in a dire prognosis. A retrospective Brazilian study conducted from March 15 to May 31, 2020, among 15 adult MG patients with COVID-19, showed a $30 \%$ mortality rate [100]. The most common presentation was dyspnea, followed by fever. Within about 2 weeks, patients needed ICU care with a $73 \%$ intubation rate. One study [101] reported a 56-year-old woman who developed an MG crisis with concomitant COVID-19 had improvement in ventilator settings after receiving IVIG. In this case, the combined use of hydroxychloroquine and azithromycin possibly aggravated MG, requiring additional doses of IVIG, which may increase the risk of adverse reactions, including thrombosis that is common among severe COVID-19 cases [102, 103]. 


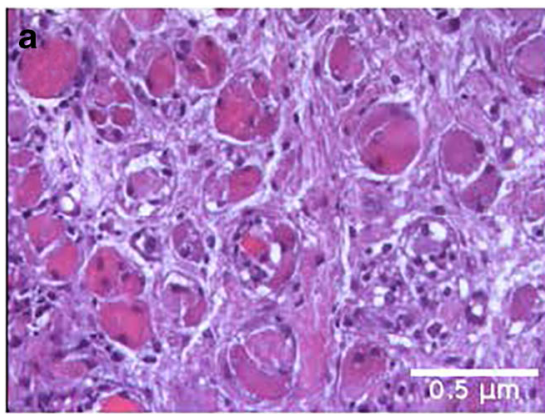

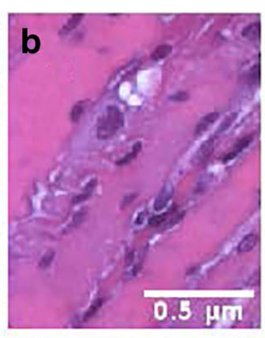

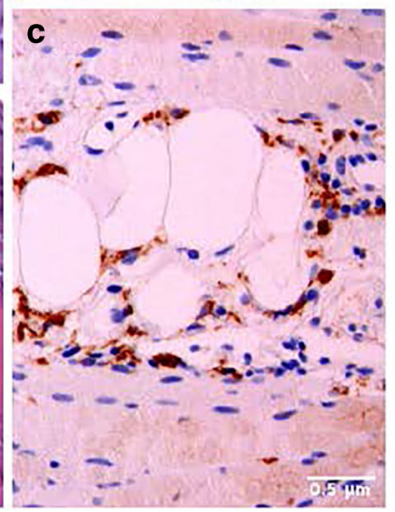

e

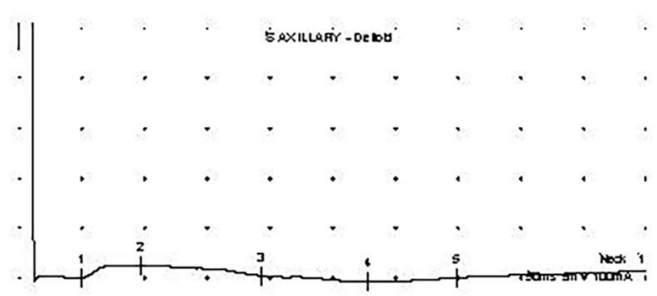

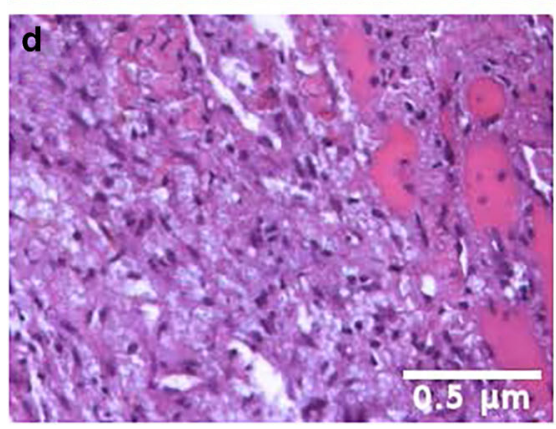

Fig. 1 Diagnostic accuracy of muscle biopsy and electromyography in COVID-19-associated myopathy. Hematoxylin and eosin formalin-fixed and paraffin-embedded tissue sections from multiple biopsies of the left deltoid muscle and the left biceps brachial muscle. Panel a Scattered myofibers undergoing various stages of necrosis, with many atrophic muscular fibers, and nuclear centralization. Panel b An example of myophagocytosis. A macrophage (in blue) is phagocytizing a myofiber. Panel c immunostaining using CD68/PGM1+ antibodies demonstrates that the inflammatory infiltrate is mainly composed of macrophages. Scant lymphocytes B/CD20+ and T/CD3+ with a T-helper immunophenotype (CD4+) as well as $\mathrm{CD} 123+$ plasmacytoid dendritic cells were also found (data not shown). Panel $\mathbf{d}$ Other non-specific

Plasmapheresis therapy for MG may be of a limited option in critically ill patients due to unstable hemodynamic status. The International MG/COVID-19 Working Group has published a guideline for MG and Lambert-Eaton myasthenic syndrome management in the COVID-19 pandemic [104].

\section{Neuro-ophthalmological Disorders}

In 11 adult patients with COVID-19, on optical coherence tomography, hyperreflective lesions at the ganglion cells' level and inner plexiform layers were found, especially at the papillomacular bundle of both eyes [105]. In the ALBACOVID registry, optic neuritis was seen in one of 841 COVID-19 patients [71••].

A 36-year-old COVID-19 patient with a history of infantile strabismus presented with diplopia and partial left oculomotor palsy shown by left mydriasis, mild eyelid ptosis, limited depression, and adduction [106]. Abduction was bilaterally limited, consistent with bilateral abducens palsies. Lower extremity hyporeflexia and hypesthesia, and gait ataxia were also noted. On MRI, there was a T2 hyperintensity and features are focal tissue sclerosis, atrophy, and variation in muscle fiber size. Panel e The electromyogram may be useful early in the diagnostic workup to confirm the presence of a myopathic pattern. Motor nerve conduction study from affected muscle (deltoid) shows compound muscle action potential (CMAP) amplitude reduced, with preserved distal latencies (top), reflecting muscle damage in the face of normal nerve function. Muscles tested by concentric needle (bottom) show short-duration, polyphasic low-amplitude motor unit potentials (MUP). Because each small motor unit is able to generate only a reduced amount of force compared with normal, with little muscle contraction, many MUPs are recruited. EMG traces were kindly supplied by Dr. Flavio Di Stasio, MD, and Dr. Giuliano Gentili, RNT

enlargement of the left oculomotor nerve. His symptoms deteriorated with worsening left eyelid ptosis, complete loss of depression, horizontal eye movements on the left, and loss of abduction on the right. Moreover, a 24-year woman in Morocco developed diplopia and strabismus of the left eye 3 days after the onset of COVID-19 symptoms [107]. She was diagnosed as having an acute painless third partial cranial nerve palsy.

\section{Sensorineural Hearing Loss}

Auditory complications have also been reported in COVID-19 patients. Munro et al. [108], in a self-reporting survey, followed up 138 adults with severe COVID-19 symptoms for hearing and/or tinnitus 8 weeks after discharge from the hospital. Sixteen $(13.2 \%)$ patients reported a change in hearing and/or tinnitus after the COVID-19 diagnosis.

Sensorineural hearing loss (SNHL) is a complication of several viral infections. However, in COVID-19, auditory complications are rare manifestations. A Thai case report describes an elderly female with COVID-19 causing SNHL 
[109]. A 52-year-old confirmed case of COVID-19 without typical symptoms experienced sudden onset left-sided hearing loss, preceded by gradually worsening tinnitus [110]. Otoscopy showed bilateral normal external auditory canals and tympanic membranes. Tuning fork tests demonstrated a positive Rinne test bilaterally, although the Weber test was lateralized to the right side. Brain MRI scans, including the internal auditory meatus and cerebellopontine angles, were unremarkable. Kilic et al. [111] studied five Turkish male patients with the sole complaint of unilateral SNHL who visited their otolaryngology outpatient clinic in April 2020 and found that one of the patients was COVID-19 positive. Another case report of a 60-year-old COVID-19 patient with hyperactive delirium [112] who developed bilateral deafness with tinnitus confirmed by acoustic evoked potential after his delirium resolved. Audiologic testing revealed complete deafness on the right side and profound sensorineural hearing loss on the left side. MRI demonstrated a partially decreased fluid signal in the cochlear basal turn of the right cochlea and a pronounced contrast enhancement in the right cochlea. In addition, meningeal contrast enhancement was observed at the base of the right temporal lobe adjacent to the temporal bone. A common practice is the use of systemic corticosteroids as initial therapy for SNHL. Neither of the two latter cases used systemic corticosteroid therapy, rather intratympanic triamcinolone injections [112] and COVID-19 treatment were utilized [111].

\section{Acute Care-Related Peripheral Nervous System Complications}

A host of patients with severe COVID-19 require acute care, and many of them are likely to have prolonged ICU stays. Therefore, these patients are at risk of developing acute carerelated PNS complications. Literature prior to the COVID-19 pandemic established that $24 \%$ to $80 \%$ of ICU survivors develop severe neuromuscular weakness, with slow recovery and profound disability $[113,114]$.

ICU-acquired weakness, including critical illness polyneuropathy (CIN) and myopathy (CIM), have been identified in many patients recovering from prolonged mechanical ventilation due to severe COVID-19. Frithof et al. [115] studied 111 COVID-19 patients and found that 11 developed CIN or CIM. There was a high incidence of CIN or CIM in COVID-19 patients compared with the general ICU patients during 2019 (9.9\% and 3.4\%, respectively). The general ICU patients had sepsis $(n=2)$, pneumonia $(n=1)$, herpes encephalitis $(n=1)$, meningitis $(n=1)$, subarachnoidal hemorrhage $(n=4)$, and subdural hematoma $(n=1)$. CIN was found to have a higher frequency in the COVID-19 ICU cases (50\%) than in the non-COVID-19 ICU cases (0\%). A 68-year-old man with COVID-19 intubated in ICU showed severe symmetrical proximal and distal weakness of $2 / 5$ according to MRC, diffuse muscle wasting, and absent deep tendon reflexes [116]. On day 65 of hospitalization, EMG-NCS was consistent with CIP. Another COVID-19 patient showed diffuse and symmetrical muscle weakness after a long stay in ICU [117]. Her NCS showed normal sensory conduction and low-amplitude compound muscle action potentials; even so, her EMG revealed signs of myopathy that was more pronounced in the lower limbs. The direct stimulation of muscle motor points showed a compound muscle action potentials with decreased amplitude on the tibialis anterior and absent on the quadriceps. Accordingly, a diagnosis of CIM was made.

COVID-19 patients may present with nerve entrapment secondary to large hematomas or another fluid buildup during their hospital stay. SARS-CoV-2 may result in thrombotic complications [118], and many COVID-19 patients may be treated with anticoagulants during their hospital course. Therefore, the risk of hematoma development should be considered in these patients [119].

\section{Potential Neurological Issues with the Prone Positioning in Hospitalized COVID-19 Patients}

Prone positioning has been recommended to treat ARDS in COVID-19 patients because of improved ventilationperfusion matching, optimized chest wall mechanics, recruitment of lung dependent regions, and enhanced drainage of tracheobronchial secretions [120]. However, several neurological issues may arise from prone positioning. This positioning may lead to a rise in intracranial pressure [121], brachial plexus damage [122], and radial, median, and sciatic nerve injury.

A 62-year-old patient with COVID-19 required respiratory assistance for 16 days [123]. During this period, prone positioning was regularly utilized. After the removal of the orotracheal intubation tube, the patient suffered dysphonia and swallowing difficulties. He thereafter showed left-sided tongue deviation indicating hypoglossal nerve injury. On nasofibroscopy, a paralysis of the left vocal cord in the abducted position, suggestive of paralysis of the vagus nerve was shown. The neurological status did not improve, even a month later. Although Tapia syndrome, i.e., the concomitant paralysis of the hypoglossal (XIIth) and vagus (Xth) nerves, is likely to be due to the compression or stretching of these nerves on the extracranial course due to airway manipulation under the prone positioning, in this case, the possible role of direct viral infection or virus-mediated immune response mechanisms should not be ignored.

Malik et al. [124] studied 83 patients after hospitalization for ARDS due to COVID-19. Of these patients, 12 (14.5\%) showed peripheral nerve injury. Except for one, the rest of the 
patients $(91.7 \%)$ had a history of prone positioning in the acute care unit. Twenty-one sites of focal peripheral nerve injury were found in these patients. Among the 12 patients with peripheral nerve injury, one had distal symmetric polyneuropathy. $76.2 \%$ of these peripheral nerve injuries were found in the upper limb. The most common site of injury was the ulnar nerve (28.6\%), followed by the radial nerve (14.3\%), the sciatic nerve (14.3\%), the brachial plexus $(9.5 \%)$, and the median nerve $(9.5 \%)$. Using EMG-NCS, the authors found nineteen peripheral nerve injury sites, of which $94.7 \%$ showed Seddon classification of axonotmesis.

\section{Vaccine-Related Peripheral Nerve Syndromes}

On December 11, 2020, the Food and Drug Administration (FDA) granted Emergency Use Authorization (EUA) for the BNT-162b2 SARS-CoV-2 vaccine in individuals 16 years and older (Pfizer Inc. [125]). On December 18, 2020, the US FDA granted EUA for the mRNA-1273 SARS-CoV-2 vaccine that encodes the S-2P antigen in individuals 18 years and older (Moderna [126]). The European Medical Agency (EMA) also adopted this accelerated procedure granting a conditional marketing authorization in Europe a few weeks after. In 2021, the promise of these vaccines to control the pandemic is becoming a reality. These vaccines are up to 95\% effective against clinically evident COVID-19. Both vaccines were well tolerated in early trials. The safety profile of BNT162b2 was characterized by short-term, mild-tomoderate pain at the injection site, fatigue, and headache. The incidence of serious adverse events was low, and no serious safety concerns were observed. Short-term mild-tomoderate pain at the injection site was the most commonly reported reaction, and severe pain occurred in less than $1 \%$ of participants across all age groups. The proportion of participants reporting local reactions did not increase after the second dose. In the mRNA-1273 SARS-CoV-2 vaccine trial (COVE trial, Moderna), Bell's palsy occurred in the vaccine group (3 participants $(<0.1 \%)$ ) and the placebo group (1 participant $(<0.1 \%)$ ) during the observation period of the trial [126]. Overall, the local reactions to vaccination were mild; however, moderate-to-severe systemic side effects, such as fatigue, myalgia, arthralgia, and headache, were noted in about $50 \%$ of participants in the mRNA-1273 group after the second dose. These side effects were transient, starting about $15 \mathrm{~h}$ after vaccination and resolved in most participants by day 2 , without sequelae. The anecdotal finding of a slight excess of Bell's palsy in this trial and in the BNT162b2 vaccine trial may be more than a chance event, but the incidence was extremely low. For example, in the Pfizer-BioNTech clinical trial, which included 44,000 participants, 4 people reported experiencing Bell's palsy, a total of $0.0091 \%$ of participants. The events were reported 3,9,37, and 48 days after vaccination. No cases of Bell's palsy were reported in the placebo group [127]. In the Moderna trial, which included 30,400 participants, 3 people $(0.099 \%)$ reported experiencing Bell's palsy. One person was in the placebo group. Among the three not in the placebo group, the Bell's palsy incidents were reported 32, 28, and 22 days after vaccination [128]. Although these rates are not higher than expected, the FDA recommends surveillance for Bell's palsy as the vaccines are distributed to the general population.

A third vaccine, AZD-1222 (ChAdOx 1 nCoV-19; AstraZeneca), is a replication-deficient chimpanzee adenoviral vector vaccine containing the surface glycoprotein antigen (spike protein) gene. This vaccine primes the immune system by eliciting antibodies to attack the SARS-CoV-2 virus. The study was briefly put on hold on September 6, 2020, after a study participant in the UK was diagnosed with transverse myelitis. After FDA review in the USA, phase 3 trials resumed there on October 23, 2020. As the follow-up period for vaccine-related complications for all of the available trials has been brief (months), future complications will be closely monitored. Still, the efficacy and safety of these novel vaccines appear to be incredibly robust.

\section{Concluding Remarks}

It is widely acknowledged that COVID-19 can influence the CNS and PNS. The literature has been flooded by reports of a broad spectrum of neurological manifestations due to COVID-19. SARS-CoV-2 may lead directly to these manifestations or deterioration of an existing medical condition. Not only does COVID-19 cause CNS involvement but also it shows PNS manifestations. The growing number of reports concerning PNS manifestations associated with COVID-19 necessitates further vigilance for early and careful diagnosis and therapy. Undoubtedly, there is a pressing need to shed light on the underlying mechanisms that result in SARSCoV-2-associated neurological manifestations. However, we must keep in mind that during the pandemic scenario, the biopsy and autopsy cases described and validated are still scarce in PNS pathology; some symptoms and signs of PNS involvement were not always framed correctly with differential diagnosis. The most common pathological pictures in COVID-19 patients seem to be similar to those observed in other viral and systemic diseases, and many of the proposed described associations are probably incidental and may not have a causal relationship with COVID-19 infection.

Acknowledgments The authors dedicate this work to all the innocent lives lost to COVID-19 around the world, particularly to Dr. Reza Azarpazhooh's mother (Shirin Vosooghi), Dr. Michel Torbey's father (Tony Torbey), and Dr. Mostafa Jafari's mother (Fatima Jafari). May their memories be in our hearts forever. The editors would like to thank Dr. John Brust for taking the time to review this manuscript. 


\section{Declarations}

Conflict of Interest Sasan Andalib, José Biller, Mario Di Napoli, Narges Moghimi, Louise D McCullough, Clio A. Rubinos, Christa O'Hana Nobleza, M. Reza Azarpazhooh, Luciana Catanese, Isabel Elicer, Mostafa Jafari, Fabrizio Liberati; Claudia Camejo, Michel Torbey, and Afshin A. Divani each declare no potential conflicts of interest.

Human and Animal Rights and Informed Consent This article does not contain any studies with human or animal subjects performed by any of the authors.

\section{References}

Papers of particular interest, published recently, have been

highlighted as:

- Of importance

-• Of major importance

1. He F, Deng Y, Li W. Coronavirus disease 2019: what we know? J Med Virol. 2020;92(7):719-25. https://doi.org/10.1002/jmv. 25766.

2. Wang Y, Wang Y, Chen Y, Qin Q. Unique epidemiological and clinical features of the emerging 2019 novel coronavirus pneumonia (COVID-19) implicate special control measures. J Med Virol. 2020;92:568-76. https://doi.org/10.1002/jmv.25748.

3. Divani AA, Andalib S, Biller J, Napoli DM, Moghimi N, Rubinos CA, et al. Central nervous system manifestations associated with COVID-19. Curr Neurol Neurosci Rep. 2020;20(12):60. https:// doi.org/10.1007/s11910-020-01079-7 A review focusing of centeral nervous system manifestations of COVID-19.

4. Donoghue M, Hsieh F, Baronas E, Godbout K, Gosselin M, Stagliano N, et al. A novel angiotensin-converting enzyme-related carboxypeptidase (ACE2) converts angiotensin I to angiotensin 19. Circ Res. 2000;87(5):E1-9. https://doi.org/10.1161/01.res.87.5. e1.

5. Ohtsuki M, Morimoto SI, Izawa H, Ismail TF, Ishibashi-Ueda H, Kato Y, et al. Angiotensin converting enzyme 2 gene expression increased compensatory for left ventricular remodeling in patients with end-stage heart failure. Int J Cardiol. 2010;145(2):333-4. https://doi.org/10.1016/j.ijcard.2009.11.057.

6. Tipnis SR, Hooper NM, Hyde R, Karran E, Christie G, Turner AJ. A human homolog of angiotensin-converting enzyme. Cloning and functional expression as a captopril-insensitive carboxypeptidase. J Biol Chem. 2000;275(43):33238-43. https://doi.org/10. 1074/jbc.M002615200.

7. Ferrario CM, Varagic J. The ANG-(1-7)/ACE2/mas axis in the regulation of nephron function. Am J Physiol Renal Physiol. 2010;298(6):F1297-305. https://doi.org/10.1152/ajprenal.00110. 2010.

8. Cheng H, Wang Y, Wang GQ. Organ-protective effect of angiotensin-converting enzyme 2 and its effect on the prognosis of COVID-19. J Med Virol. 2020;92(7):726-30. https://doi.org/ 10.1002/jmv.25785.

9. Iadecola C, Anrather J, Kamel H. Effects of COVID-19 on the nervous system. Cell. 2020;183(1):16-27.e1. https://doi.org/10. 1016/j.cell.2020.08.028.

10. Divani AA, Andalib S, Di Napoli M, Lattanzi S, Hussain MS, Biller J, et al. Coronavirus disease 2019 and stroke: clinical manifestations and pathophysiological insights. J Stroke Cerebrovasc Dis. 2020;29(8):104941. https://doi.org/10.1016/j. jstrokecerebrovasdis.2020.104941 A review summarizing the clinical and pathophysiological aspects of stroke in COVID19.

11. Bilinska K, Jakubowska P, Von Bartheld CS, Butowt R. Expression of the SARS-CoV-2 entry proteins, ACE2 and TMPRSS2, in cells of the olfactory epithelium: identification of cell types and trends with age. ACS Chem Neurosci. 2020;11(11): 1555-62. https://doi.org/10.1021/acschemneuro.0c00210.

12. de Freitas Ferreira ACA, Romão TT, Silva Macedo Y, Pupe C, Nascimento OJ. COVID-19 and herpes zoster co-infection presenting with trigeminal neuropathy. Eur J Neurol. 2020. https:// doi.org/10.1111/ene.14361.

13. Zubair AS, McAlpine LS, Gardin T, Farhadian S, Kuruvilla DE, Spudich S. Neuropathogenesis and neurologic manifestations of the coronaviruses in the age of coronavirus disease 2019: a review. JAMA Neurol. 2020;77(8):1018-27. https://doi.org/10.1001/ jamaneurol.2020.2065.

14. Matschke J, Lütgehetmann M, Hagel C, Sperhake JP, Schröder AS, Edler C, et al. Neuropathology of patients with COVID-19 in Germany: a post-mortem case series. Lancet Neurol. 2020;19(11): 919-29. https://doi.org/10.1016/s1474-4422(20)30308-2.

15. Schurink B, Roos E, Radonic T, Barbe E, Bouman CSC, de Boer $\mathrm{HH}$, et al. Viral presence and immunopathology in patients with lethal COVID-19: a prospective autopsy cohort study. Lancet Microbe. 2020;1(7):e290-e9. https://doi.org/10.1016/s26665247(20)30144-0.

16. Song E, Zhang C, Israelow B, Lu-Culligan A, Prado AV, Skriabine S, et al. Neuroinvasion of SARS-CoV-2 in human and mouse brain. bioRxiv. 2020. https://doi.org/10.1101/2020.06.25. 169946.

17. Solomon IH, Normandin E, Bhattacharyya S, Mukerji SS, Keller $\mathrm{K}$, Ali AS, et al. Neuropathological features of Covid-19. N Engl J Med. 2020. https://doi.org/10.1056/NEJMc2019373.

18. Fajgenbaum DC, June CH. Cytokine Storm. NEJM. 2020;383(23):2255-73. https://doi.org/10.1056/ NEJMra2026131.

19. Vaninov N. In the eye of the COVID-19 cytokine storm. Nat Rev Immunol. 2020;20:277. https://doi.org/10.1038/s41577-0200305-6.

20. Conti P, Ronconi G, Caraffa A, Gallenga C, Ross R, Frydas I, et al. Induction of pro-inflammatory cytokines (IL-1 and IL-6) and lung inflammation by coronavirus-19 (COVI-19 or SARS-CoV2): anti-inflammatory strategies. J Biol Regul Homeost Agents. 2020;34(2). https://doi.org/10.23812/CONTI-E.

21. Marchetti C, Swartzwelter B, Koenders MI, Azam T, Tengesdal IW, Powers N, et al. NLRP3 inflammasome inhibitor OLT1177 suppresses joint inflammation in murine models of acute arthritis. Arthritis Res Ther. 2018;20(1):169. https://doi.org/10.1186/ s13075-018-1664-2.

22. Payus AO, Lin CLS, Noh MM, Jeffree MS, RAJBJoBMS A. SARS-CoV-2 infection of the nervous system: a review of the literature on neurological involvement in novel coronavirus disease (COVID-19). Bosn J Basic Med Sci. 2020;20(3):283-92. https://doi.org/10.17305/bjbms.2020.4860.

23. Kany S, Vollrath JT, Relja B. Cytokines in inflammatory disease. Int J Mol Sci. 2019;20(23). https://doi.org/10.3390/ ijms20236008.

24. Shaafi S, Sharifipour E, Rahmanifar R, Hejazi S, Andalib S, Nikanfar M, et al. Interleukin-6, a reliable prognostic factor for ischemic stroke. Iran J Neurol. 2014;13(2):70-6.

25. Wan Y, Shang J, Graham R, Baric RS, Li F. Receptor recognition by the novel coronavirus from Wuhan: an analysis based on decade-long structural studies of SARS coronavirus. J Virol. 2020;94(7). https://doi.org/10.1128/jvi.00127-20.

26. Huang C, Wang Y, Li X, Ren L, Zhao J, Hu Y, et al. Clinical features of patients infected with 2019 novel coronavirus in 
Wuhan, China. Lancet. 2020;395(10223):497-506. https://doi. org/10.1016/s0140-6736(20)30183-5.

27. McNab F, Mayer-Barber K, Sher A, Wack A, O'garra A. Type I interferons in infectious disease. Nat Rev Immunol. 2015;15(2): 87-103. https://doi.org/10.1038/nri3787.

28. Alberti P, Beretta S, Piatti M, Karantzoulis A, Piatti ML, Santoro $\mathrm{P}$, et al. Guillain-Barré syndrome related to COVID-19 infection. Neurol Neuroimmunol Neuroinflamm. 2020;7(4):e741. https:// doi.org/10.1212/NXI.0000000000000741.

29. Studart-Neto A, Guedes BF, Tuma RLE, Camelo Filho AE, Kubota GT, Iepsen BD, et al. Neurological consultations and diagnoses in a large, dedicated COVID-19 university hospital. Arquivos de neuro-psiquiatria. 2020;78(8):494-500. https://doi. org/10.1590/0004-282x20200089.

30. McGonagle D, Sharif K, O'Regan A, Bridgewood C. The Role of Cytokines including Interleukin-6 in COVID-19 induced Pneumonia and Macrophage Activation Syndrome-Like Disease. Autoimmun Rev. 2020;19(6):102537. https://doi.org/10.1016/j. autrev.2020.102537.

31. Needham E, Newcombe V, Michell A, Thornton R, Grainger A, Anwar F, et al. Mononeuritis multiplex: an unexpectedly frequent feature of severe COVID-19. Journal of Neurology. 2020. https:// doi.org/10.1007/s00415-020-10321-8.

32. Willison HJ, Jacobs BC, van Doorn PA. Guillain-Barré syndrome. Lancet. 2016;388(10045):717-27. https://doi.org/10.1016/s01406736(16)00339-1.

33. Leonhard SE, Mandarakas MR, Gondim FAA, Bateman K, Ferreira MLB, Cornblath DR, et al. Diagnosis and management of GuillainBarré syndrome in ten steps. Nat Rev Neurol. 2019;15(11):671-83. https://doi.org/10.1038/s41582-019-0250-9.

34. Kim JE, Heo JH, Kim HO, Song SH, Park SS, Park TH, et al. Neurological complications during treatment of Middle East respiratory syndrome. J Clin Neurol. 2017;13(3):227-33. https:// doi.org/10.3988/jen.2017.13.3.227.

35. Tsai LK, Hsieh ST, Chang YC. Neurological manifestations in severe acute respiratory syndrome. Acta Neurol Taiwan. 2005;14(3):113-9.

36. Zhao H, Shen D, Zhou H, Liu J, Chen S. Guillain-Barré syndrome associated with SARS-CoV-2 infection: causality or coincidence? Lancet Neurol. 2020;19(5):383-4. https://doi.org/10.1016/S14744422(20)30109-5.

37. Abdelnour L, Eltahir Abdalla M, Babiker S. COVID 19 infection presenting as motor peripheral neuropathy. J Formos Med Assoc. 2020;119(6):1119-20. https://doi.org/10.1016/j.jfma.2020.04. 024 .

38. Caress JB, Castoro RJ, Simmons Z, Scelsa SN, Lewis RA, Ahlawat A, et al. COVID-19-associated Guillain-Barré syndrome: the early pandemic experience. Muscle Nerve. 2020;62(4):48591. https://doi.org/10.1002/mus.27024.

39. Zito A, Alfonsi E, Franciotta D, Todisco M, Gastaldi M, Cotta Ramusino M, et al. COVID-19 and Guillain-Barré syndrome: a case report and review of literature. Front Neurol. 2020;11:909. https://doi.org/10.3389/fneur.2020.00909.

40. Virani A, Rabold E, Hanson T, Haag A, Elrufay R, Cheema T, et al. Guillain-Barré syndrome associated with SARS-CoV-2 infection. IDCases. 2020:e00771. https://doi.org/10.1016/j.idcr. 2020.e00771.

41. Toscano G, Palmerini F, Ravaglia S, Ruiz L, Invernizzi P, Cuzzoni MG, et al. Guillain-Barré syndrome associated with SARS-CoV-2. N Eng J Med. 2020;382:2574-6. https://doi.org/ 10.1056/NEJMc2009191.

42. Chan JL, Ebadi H, Sarna JR. Guillain-Barré syndrome with facial diplegia related to SARS-CoV-2 infection. Can J Neurol Sci. 2020:1-3. https://doi.org/10.1017/cjn.2020.106.

43. Hutchins KL, Jansen JH, Comer AD, Scheer RV, Zahn GS, Capps $\mathrm{AE}$, et al. COVID-19-associated bifacial weakness with paresthesia subtype of Guillain-Barré syndrome. Am J Neuroradiol. 2020;41(9):1707-11. https://doi.org/10.3174/ajnr. a6654.

44. Ottaviani D, Boso F, Tranquillini E, Gapeni I, Pedrotti G, Cozzio $\mathrm{S}$, et al. Early Guillain-Barré syndrome in coronavirus disease 2019 (COVID-19): a case report from an Italian COVID-hospital. Neurol Sci. 2020:1-4. https://doi.org/10.1007/s10072-02004449-8.

45. Juliao Caamaño DS, Alonso Beato R. Facial diplegia, a possible atypical variant of Guillain-Barré Syndrome as a rare neurological complication of SARS-CoV-2. J Clin Neurosci. 2020. https://doi. org/10.1016/j.jocn.2020.05.016.

46. Padroni M, Mastrangelo V, Asioli GM, Pavolucci L, AbuRumeileh S, Piscaglia MG, et al. Guillain-Barré syndrome following COVID-19: new infection, old complication? J Neurol. 2020: 1-3. https://doi.org/10.1007/s00415-020-09849-6.

47. Sedaghat Z, Karimi N. Guillain Barre syndrome associated with COVID-19 infection: A case report. J Clin Neurosci. 2020:S09675868(20)30882-1. https://doi.org/10.1016/j.jocn.2020.04.062.

48. Coen M, Jeanson G, Culebras Almeida LA, Hübers A, Stierlin F, Najjar I, et al. Guillain-Barré syndrome as a complication of SARS-CoV-2 infection. Brain Behav Immun. 2020:S08891591(20)30698-X. https://doi.org/10.1016/j.bbi.2020.04.074.

49. Camdessanche JP, Morel J, Pozzetto B, Paul S, Tholance Y, Botelho-Nevers E. COVID-19 may induce Guillain-Barré syndrome. Rev Neurol (Paris). 2020;176(6):516-8. https://doi.org/ 10.1016/j.neurol.2020.04.003.

50. Gutiérrez-Ortiz C, Méndez A, Rodrigo-Rey S, San Pedro-Murillo E, Bermejo-Guerrero L, Gordo-Mañas R, et al. Miller Fisher syndrome and polyneuritis cranialis in COVID-19. Neurology. 2020. https://doi.org/10.1212/wnl.0000000000009619.

51. Lantos JE, Strauss SB, Lin E. COVID-19-associated Miller Fisher syndrome: MRI findings. AJNR Am J Neuroradiol. 2020;41(7): 1184-6. https://doi.org/10.3174/ajnr.A6609.

52. Rana S, Lima AA, Chandra R, Valeriano J, Desai T, Freiberg W et al. Novel Coronavirus (COVID-19)-associated Guillain-Barré syndrome: case report. J Clin Neuromuscul Dis. 2020;21(4):2402. doi:https://doi.org/10.1097/CND.0000000000000309.

53. Reyes-Bueno JA, García-Trujillo L, Urbaneja P, Ciano-Petersen NL, Postigo-Pozo MJ, Martínez-Tomás C, et al. Miller-Fisher syndrome after SARS-CoV-2 infection. Eur J Neurol. 2020. https://doi.org/10.1111/ene.14383.

54. Senel M, Abu-Rumeileh S, Michel D, Garibashvili T, Althaus K, Kassubek J, et al. Miller-Fisher syndrome after COVID-19: neurochemical markers as an early sign of nervous system involvement. Eur J Neurol. 2020;27(11):2378-80. https://doi.org/10. 1111/ene. 14473.

55. Fernández-Domínguez J, Ameijide-Sanluis E, García-Cabo C, García-Rodríguez R, Mateos V. Miller-Fisher-like syndrome related to SARS-CoV-2 infection (COVID 19). J Neurol. 2020;267(9): 2495-6. https://doi.org/10.1007/s00415-020-09912-2.

56. Manganotti P, Pesavento V, Buoite Stella A, Bonzi L, Campagnolo E, Bellavita G, et al. Miller Fisher syndrome diagnosis and treatment in a patient with SARS-CoV-2. J Neurovirol. 2020;26(4):605-6. https://doi.org/10.1007/s13365-020-00858-9.

57. Diez-Porras L, Vergés E, Gil F, Vidal MJ, Massons J, Arboix A. Guillain-Barré-Strohl syndrome and COVID-19: case report and literature review. Neuromuscular disorders : NMD. 2020:S09608966(20)30551-4. https://doi.org/10.1016/j.nmd.2020.08.354.

58. Paybast S, Gorji R, Mavandadi S. Guillain-Barré syndrome as a neurological complication of novel COVID-19 infection: a case report and review of the literature. The neurologist. 2020;25(4): 101-3. https://doi.org/10.1097/NRL.0000000000000291.

59. Assini A, Benedetti L, Di Maio S, Schirinzi E, Del Sette M. New clinical manifestation of COVID-19 related Guillain-Barrè syndrome highly responsive to intravenous immunoglobulins: two 
Italian cases. Neurol Sci. 2020;41(7):1657-8. https://doi.org/10. 1007/s10072-020-04484-5.

60. Su XW, Palka SV, Rao RR, Chen FS, Brackney CR, Cambi F. SARS-CoV-2-associated Guillain-Barré syndrome with dysautonomia. Muscle Nerve. 2020;62(2):E48-e9. https://doi. org/10.1002/mus.26988.

61. Scheidl E, Canseco DD, Hadji-Naumov A, Bereznai B. GuillainBarré syndrome during SARS-CoV-2 pandemic: a case report and review of recent literature. J Peripher Nerv Syst. 2020;25(2):204 7. https://doi.org/10.1111/jns.12382.

62. Oguz-Akarsu E, Ozpar R, Mirzayev H, Acet-Ozturk NA, Hakyemez B, Ediger D, et al. Guillain-Barré syndrome in a patient with minimal symptoms of COVID-19 infection. Muscle \& nerve. 2020;62(3):E54-E7. https://doi.org/10.1002/mus.26992.

63. El Otmani H, El Moutawakil B, Rafai MA, El Benna N, El Kettani C, Soussi M, et al. Covid-19 and Guillain-Barré syndrome: more than a coincidence! Rev Neurol (Paris). 2020;176(6):518-9. https://doi.org/10.1016/j.neurol.2020.04.007.

64. Bigaut K, Mallaret M, Baloglu S, Nemoz B, Morand P, Baicry F, et al. Guillain-Barré syndrome related to SARS-CoV-2 infection. Neurol Neuroimmunol Neuroinflamm. 2020;7(5):e785. https:// doi.org/10.1212/nxi.0000000000000785.

65. Arnaud S, Budowski C, Ng Wing Tin S, Degos B. Post SARSCoV-2 Guillain-Barré syndrome. Clin Neurophysiol. 2020;131(7):1652-4. https://doi.org/10.1016/j.clinph.2020.05. 003 .

66. Esteban Molina A, Mata Martínez M, Sánchez Chueca P, Carrillo López A, Sancho Val I, Sanjuan-Villarreal TA. Guillain-Barré syndrome associated with SARS-CoV-2 infection. Med Intensiva. 2020;44(8):513-4. https://doi.org/10.1016/j.medin. 2020.04.015.

67. Marta-Enguita J, Rubio-Baines I, Gastón-Zubimendi I. Fatal Guillain-Barre syndrome after infection with SARS-CoV-2. Neurologia. 2020;35(4):265-7. https://doi.org/10.1016/j.nrl. 2020.04.004.

68. Sancho-Saldaña A, Lambea-Gil Á, Liesa JLC, Caballo MRB, Garay MH, Celada DR, et al. Guillain-Barré syndrome associated with leptomeningeal enhancement following SARS-CoV-2 infection. Clin Med (Lond). 2020;20(4):e93-e4. https://doi.org/10. 7861/clinmed.2020-0213.

69. Velayos Galán A, del Saz Saucedo P, Peinado Postigo F, Botia Paniagua E. Guillain-Barré syndrome associated with SARSCoV-2 infection. Neurología (English Edition). 2020;35(4):2689. https://doi.org/10.1016/j.nrleng.2020.04.006.

70. Webb S, Wallace VC, Martin-Lopez D, Yogarajah M. GuillainBarré syndrome following COVID-19: a newly emerging postinfectious complication. BMJ Case Reports. 2020;13(6): e236182. https://doi.org/10.1136/bcr-2020-236182.

71.• Romero-Sánchez CM, Díaz-Maroto I, Fernández-Díaz E, Sánchez-Larsen Á, Layos-Romero A, García-García J, et al. Neurologic manifestations in hospitalized patients with COVID19: the ALBACOVID registry. Neurology. 2020. https://doi.org/ 10.1212/WNL.0000000000009937 ALBACOVID registry reported myalgias, myopathy, and optic neuritis in patients with COVID-19.

72.• De Sanctis P, Doneddu PE, Viganò L, Selmi C, Nobile-Orazio E. Guillain-Barré syndrome associated with SARS-CoV-2 infection. A systematic review. Eur J Neurol. 2020. https://doi.org/10.1111/ ene.14462 A systematic review giving account of GuillainBarré syndrome (GBS) associated with COVID-19.

73. Gupta A, Paliwal VK, Garg RK. Is COVID-19-related GuillainBarré syndrome different? Brain Behav Immun. 2020;87:177-8. https://doi.org/10.1016/j.bbi.2020.05.051.

74. Abu-Rumeileh S, Abdelhak A, Foschi M, Tumani H, Otto M. Guillain-Barré syndrome spectrum associated with COVID-19: an up-to-date systematic review of 73 cases. J Neurol. 2020:138. https://doi.org/10.1007/s00415-020-10124-x.

75. Uncini A, Vallat JM, Jacobs BC. Guillain-Barré syndrome in SARS-CoV-2 infection: an instant systematic review of the first six months of pandemic. J Neurol Neurosurg Psychiatry. 2020;91(10):1105-10. https://doi.org/10.1136/jnnp-2020324491.

76. Keddie S, Pakpoor J, Mousele C, Pipis M, Machado PM, Foster $\mathrm{M}$, et al. Epidemiological and cohort study finds no association between COVID-19 and Guillain-Barré syndrome. Brain. 2020. https://doi.org/10.1093/brain/awaa433.

77. Mao L, Jin H, Wang M, Hu Y, Chen S, He Q, et al. Neurologic manifestations of hospitalized patients with coronavirus disease 2019 in Wuhan, China. JAMA Neurol. 2020;77(6):683-90. https://doi.org/10.1001/jamaneurol.2020.1127.

78. Han YN, Feng ZW, Sun LN, Ren XX, Wang H, Xue YM, et al. A comparative-descriptive analysis of clinical characteristics in 2019-coronavirus-infected children and adults. J Med Virol. 2020. https://doi.org/10.1002/jmv.25835.

79. Wang X, Liu W, Zhao J, Lu Y, Wang X, Yu C, et al. Clinical characteristics of 80 hospitalized frontline medical workers infected with COVID-19 in Wuhan, China. J Hosp Infect. 2020;105(3): 399-403. https://doi.org/10.1016/j.jhin.2020.04.019.

80. Liu M, He P, Liu HG, Wang XJ, Li FJ, Chen S, et al. Clinical characteristics of 30 medical workers infected with new coronavirus pneumonia. Zhonghua Jie He He Hu Xi Za Zhi. 2020;43(3): 209-14. https://doi.org/10.3760/cma.j.issn.1001-0939.2020.03. 014.

81. Lechien JR, Chiesa-Estomba CM, Place S, Van Laethem Y, Cabaraux P, Mat Q, et al. Clinical and epidemiological characteristics of 1420 European patients with mild-to-moderate coronavirus disease 2019. J Intern Med. 2020;288(3):335-44. https://doi. org/10.1111/joim.13089.

82. Lai X, Wang M, Qin C, Tan L, Ran L, Chen D, et al. Coronavirus disease 2019 (COVID-2019) infection among health care workers and implications for prevention measures in a tertiary hospital in Wuhan, China. JAMA network open. 2020;3(5):e209666-e. https://doi.org/10.1001/jamanetworkopen.2020.9666.

83. Lapostolle F, Schneider E, Vianu I, Dollet G, Roche B, Berdah J, et al. Clinical features of 1487 COVID-19 patients with outpatient management in the Greater Paris: the COVID-call study. Intern Emerg Med. 2020;15(5):813-7. https://doi.org/10.1007/s11739020-02379-Z

84. Chen Y, Zhao M, Wu Y, Zang S. Epidemiological analysis of the early 38 fatalities in Hubei, China, of the coronavirus disease 2019. J Glob Health. 2020;10(1):011004. https://doi.org/10. 7189/jogh-10-011004.

85. O'Reilly GM, Mitchell RD, Wu J, Rajiv P, Bannon-Murphy H, Amos T, et al. Epidemiology and clinical features of emergency department patients with suspected COVID-19: results from the first month of the COVID-19 Emergency Department Quality Improvement Project (COVED-2). Emerg Med Australas. 2020;32(5):814-22. https://doi.org/10.1111/1742-6723.13573.

86. Gaur A, Meena SK, Bairwa R, Meena D, Nanda R, Sharma SR, et al. Clinico-radiological Presentation of COVID-19 Patients at a Tertiary Care Center at Bhilwara Rajasthan, India. J Assoc Physicians India. 2020;68(7):29-33.

87. Aggarwal A, Shrivastava A, Kumar A, Ali A. Clinical and Epidemiological Features of SARS-CoV-2 Patients in SARI Ward of a Tertiary Care Centre in New Delhi. J Assoc Physicians India. 2020;68(7):19-26.

88. Xu X-W, Wu X-X, Jiang X-G, Xu K-J, Ying L-J, Ma C-L, et al. Clinical findings in a group of patients infected with the 2019 novel coronavirus (SARS-Cov-2) outside of Wuhan, China: retrospective case series. BMJ (Clinical research ed). 2020;368: m606-m. https://doi.org/10.1136/bmj.m606. 
89. Wei X-S, Wang X-R, Zhang J-C, Yang W-B, Ma W-L, Yang B$\mathrm{H}$, et al. A cluster of health care workers with COVID-19 pneumonia caused by SARS-CoV-2. J Microbiol Immunol Infect. 2020:S1684-182(20)30107-9. https://doi.org/10.1016/j.jmii. 2020.04.013.

90. Korkmaz MF, Türe E, Dorum BA, Kılıç ZB. The epidemiological and clinical characteristics of 81 children with COVID-19 in a pandemic hospital in Turkey: an observational cohort study. Journal of Korean medical science. 2020;35(25):e236-e. https:// doi.org/10.3346/jkms.2020.35.e236.

91. Beydon M, Chevalier K, Al Tabaa O, Hamroun S, Delettre AS, Thomas M, et al. Myositis as a manifestation of SARS-CoV-2. Ann Rheum Dis. 2020. https://doi.org/10.1136/annrheumdis2020-217573.

92. Zhang H, Charmchi Z, Seidman RJ, Anziska Y, Velayudhan V, Perk J. COVID-19-associated myositis with severe proximal and bulbar weakness. Muscle Nerve. 2020;62(3):E57-60. https://doi. org/10.1002/mus.27003.

93. Mehan WA, Yoon BC, Lang M, Li MD, Rincon S, Buch K. Paraspinal myositis in patients with COVID-19 infection. AJNR Am J Neuroradiol. 2020;41(10):1949-52. https://doi.org/10.3174/ ajnr.A6711.

94. Pinal-Fernandez I, Casal-Dominguez M, Mammen AL. Immunemediated necrotizing myopathy. Curr Rheumatol Rep. 2018;20(4):21. https://doi.org/10.1007/s11926-018-0732-6.

95. Vaira LA, Deiana G, Fois AG, Pirina P, Madeddu G, De Vito A, et al. Objective evaluation of anosmia and ageusia in COVID-19 patients: single-center experience on 72 cases. Head Neck. 2020;42(6):1252-8. https://doi.org/10.1002/hed.26204.

96. Homma Y, Watanabe M, Inoue K, Moritaka T. Coronavirus Disease-19 Pneumonia with Facial Nerve Palsy and Olfactory Disturbance. Intern Med. 2020;59(14):1773-5. https://doi.org/ 10.2169/internalmedicine.5014-20.

97. Gogia B, Gil Guevara A, Rai PK, Fang X. A case of COVID-19 with multiple cranial neuropathies. Int J Neurosci. 2020:1-3. https://doi.org/10.1080/00207454.2020.1869001.

98. Restivo DA, Centonze D, Alesina A, Marchese-Ragona R. Myasthenia gravis associated with SARS-CoV-2 infection. Ann Intern Med. 2020;173(12):1027-8. https://doi.org/10.7326/L200845 .

99. Gilhus NE, Romi F, Hong Y, Skeie GO. Myasthenia gravis and infectious disease. J Neurol. 2018;265(6):1251-8. https://doi.org/ 10.1007/s00415-018-8751-9.

100. Camelo-Filho AE, Silva AMS, Estephan EP, Zambon AA, Mendonça RH, Souza PVS, et al. Myasthenia gravis and COVID-19: clinical characteristics and outcomes. Front Neurol. 2020;11:1053. https://doi.org/10.3389/fneur.2020.01053.

101. Delly F, Syed MJ, Lisak RP, Zutshi D. Myasthenic crisis in COVID-19. J Neurol Sci. 2020;414:116888. https://doi.org/10. 1016/j.jns.2020.116888.

102. Marie I, Maurey G, Hervé F, Hellot MF, Levesque H. Intravenous immunoglobulin-associated arterial and venous thrombosis; report of a series and review of the literature. Br J Dermatol. 2006;155(4):714-21. https://doi.org/10.1111/j.1365-2133.2006. 07390.x.

103. Klok FA, Kruip M, van der Meer NJM, Arbous MS, Gommers D, Kant KM, et al. Incidence of thrombotic complications in critically ill ICU patients with COVID-19. Thromb Res. 2020;191:145-7. https://doi.org/10.1016/j.thromres.2020.04.013.

104. Jacob S, Muppidi S, Guidon A, Guptill J, Hehir M, Howard JF Jr, et al. Guidance for the management of myasthenia gravis (MG) and Lambert-Eaton myasthenic syndrome (LEMS) during the COVID-19 pandemic. J Neurol Sci. 2020;412:116803. https:// doi.org/10.1016/j.jns.2020.116803.

105. Marinho PM, Marcos AAA, Romano AC, Nascimento H, Belfort $\mathrm{R}$ Jr. Retinal findings in patients with COVID-19. Lancet
(London, England). 2020. https://doi.org/10.1016/S01406736(20)31014-X.

106. Dinkin M, Gao V, Kahan J, Bobker S, Simonetto M, Wechsler P, et al. COVID-19 presenting with ophthalmoparesis from cranial nerve palsy. Neurology. 2020;95(5):221-3. https://doi.org/10. 1212/wnl.0000000000009700.

107. Belghmaidi S, Nassih H, Boutgayout S, El Fakiri K, El Qadiry R, Hajji I, et al. Third cranial nerve palsy presenting with unilateral diplopia and strabismus in a 24-year-old woman with COVID-19. Am J Case Rep. 2020;21:e925897. https://doi.org/10.12659/ajcr. 925897.

108. Munro KJ, Uus K, Almufarrij I, Chaudhuri N, Yioe V. Persistent self-reported changes in hearing and tinnitus in posthospitalisation COVID-19 cases. Int J Audiol. 2020:1-2. https:// doi.org/10.1080/14992027.2020.1798519.

109. Sriwijitalai W, Wiwanitkit V. Hearing loss and COVID-19: a note. Am J Otolaryngol. 2020:102473. https://doi.org/10.1016/j. amjoto.2020.102473.

110. Abdel Rhman S, Abdel Wahid A. COVID -19 and sudden sensorineural hearing loss, a case report. Otolaryngol Case Report. 2020;16:100198. https://doi.org/10.1016/j.xocr.2020.100198.

111. Kilic O, Kalcioglu MT, Cag Y, Tuysuz O, Pektas E, Caskurlu H, et al. Could sudden sensorineural hearing loss be the sole manifestation of COVID-19? An investigation into SARS-COV-2 in the etiology of sudden sensorineural hearing loss. International journal of infectious diseases : IJID : official publication of the International Society for Infectious Diseases. 2020;97:208-11. https://doi.org/10.1016/j.ijid.2020.06.023.

112. Degen C, Lenarz T, Willenborg K. Acute profound sensorineural hearing loss after COVID-19 pneumonia. Mayo Clin Proc. 2020;95(8):1801-3. https://doi.org/10.1016/j.mayocp.2020.05.034.

113. Latronico N, Bolton CF. Critical illness polyneuropathy and myopathy: a major cause of muscle weakness and paralysis. Lancet Neurol. 2011;10(10):931-41. https://doi.org/10.1016/s14744422(11)70178-8.

114. Hough CL, Steinberg KP, Taylor Thompson B, Rubenfeld GD, Hudson LD. Intensive care unit-acquired neuromyopathy and corticosteroids in survivors of persistent ARDS. Intensive Care Med. 2009;35(1):63-8. https://doi.org/10.1007/s00134-008-1304-4.

115. Frithiof R, Rostami E, Kumlien E, Virhammar J, Fällmar D, Hultström M, et al. Critical illness polyneuropathy and myopathy in COVID-19 patients: a prospective observational intensive care unit cross-sectional cohort study. Research Square. 2020. https:// doi.org/10.21203/rs.3.rs-78038/v1.

116. Tankisi H, Tankisi A, Harbo T, Markvardsen LK, Andersen H, Pedersen TH. Critical illness myopathy as a consequence of Covid-19 infection. Clin Neurophysiol. 2020;131(8):1931-2. https://doi.org/10.1016/j.clinph.2020.06.003.

117. Bagnato S, Boccagni C, Marino G, Prestandrea C, D'Agostino T, Rubino F. Critical illness myopathy after COVID-19. Int J Infect Dis. 2020;99:276-8. https://doi.org/10.1016/j.ijid.2020.07.072.

118. Al-Ani F, Chehade S, Lazo-Langner A. Thrombosis risk associated with COVID-19 infection. A scoping review. Thromb Res. 2020;192:152-60. https://doi.org/10.1016/j.thromres.2020.05.039.

119. Fernandez CE, Franz CK, Ko JH, Walter JM, Koralnik IJ, Ahlawat S, et al. Imaging review of peripheral nerve injuries in patients with COVID-19. Radiology. 2020:203116. https://oi. org/10.1148/radiol.2020203116.

120. Moghadam VD, Shafiee H, Ghorbani M, Heidarifar R. Prone positioning in management of COVID-19 hospitalized patients. Braz J Anesthesiol. 2020;70(2):188-90. https://doi.org/10.1016/ j.bjane.2020.05.001.

121. Roth C, Ferbert A, Deinsberger W, Kleffmann J, Kästner S, Godau J, et al. Does prone positioning increase intracranial pressure? A retrospective analysis of patients with acute brain injury 
and acute respiratory failure. Neurocrit Care. 2014;21(2):186-91. https://doi.org/10.1007/s12028-014-0004-x.

122. Goettler CE, Pryor JP, Reilly PM. Brachial plexopathy after prone positioning. Critical care (London, England). 2002;6(6):540-2. https://doi.org/10.1186/cc1823.

123. Decavel P, Petit C, Tatu L. Tapia syndrome at the time of the COVID-19 pandemic: lower cranial neuropathy following prolonged intubation. Neurology. 2020;95(7):312-3. https://doi. org/10.1212/wnl.0000000000010011.

124. Malik GR, Wolfe AR, Soriano R, Rydberg L, Wolfe LF, Deshmukh $\mathrm{S}$, et al. Injury-prone: peripheral nerve injuries associated with prone positioning for COVID-19-related acute respiratory distress syndrome. Br J Anaesth. 2020;125(6):e478-e80. https://doi.org/10.1016/j.bja.2020.08.045.

125. Polack FP, Thomas SJ, Kitchin N, Absalon J, Gurtman A, Lockhart S, et al. Safety and efficacy of the BNT162b2 mRNA
Covid-19 Vaccine. NEJM. 2020;383(27):2603-15. https://doi. org/10.1056/NEJMoa2034577.

126. Baden LR, El Sahly HM, Essink B, Kotloff K, Frey S, Novak R, et al. Efficacy and safety of the mRNA-1273 SARS-CoV-2 vaccine. NEJM. 2020. https://doi.org/10.1056/NEJMoa2035389.

127. FDA. Vaccines and related biological products Advisory Committee meeting December 10, 2020. FDA briefing document: Pfizer-BioNTech COVID-19 vaccine. 2020. https://www.fda. gov/media/144245/download. Accessed Jan 32021.

128. FDA. Vaccines and related biological products Advisory Committee meeting December 17, 2020. FDA briefing document Moderna COVID-19 vaccine. December 17, 2020. 2020. https:// www.fda.gov/media/144434/download. Accessed Jan 32021.

Publisher's Note Springer Nature remains neutral with regard to jurisdictional claims in published maps and institutional affiliations.

\section{Affiliations}

\section{Sasan Andalib ${ }^{1}$ - José Biller ${ }^{2}$ Mario Di Napoli ${ }^{3}$ Narges Moghimi ${ }^{4} \cdot$ Louise D McCullough $^{5} \cdot$ Clio A. Rubinos $^{6}$. Christa O'Hana Nobleza ${ }^{7} \cdot$ M. Reza Azarpazhooh ${ }^{8} \cdot$ Luciana Catanese $^{9} \cdot$ Isabel Elicer $^{10}$. Mostafa Jafari ${ }^{11}$. Fabrizio Liberati ${ }^{12}$. Claudia Camejo ${ }^{13} \cdot$ Michel Torbey $^{4} \cdot$ Afshin A. Divani $^{4}$}

1 Research Unit of Clinical Physiology and Nuclear Medicine, Department of Clinical Research, Odense University Hospital, Faculty of Health Sciences, University of Southern Denmark, Odense, Denmark

2 Department of Neurology, Loyola University, Stritch School of Medicine, Maywood, IL, USA

3 Neurological Service, SS Annunziata Hospital, Sulmona, L'Aquila, Italy

4 Department of Neurology, School of Medicine, University of New Mexico, NM, Albuquerque, NM 87131, USA

5 Neurology Department, McGovern Medical School, University of Texas Health Sciences Center, Houston, TX, USA

6 Department of Neurology, University of North Carolina, Chapel Hill, NC, USA
7 Department of Neurology, The University of Mississippi Medical Center, Jackson, MS, USA

8 Departments of Clinical Neurological Sciences, Western University, London, Canada

9 Department of Medicine (Neurology), Hamilton Health Sciences, McMaster University, Hamilton, ON, Canada

10 Departamento de Neurologia, Red UC Christus, Hospital Dr. Sótero del Río, Clínica Las Condes, Santiago, Chile

11 Department of Neurology, Baylor College of Medicine, Houston, TX, USA

12 Department of Anatomic Pathology and Histology, San Camillo De' Lellis Hospital, Rieti, Italy

13 Hospital de Clínicas, Universidad de La Republica, Montevideo, Uruguay 